\title{
Beam Trawls and Bones: A Reflection on Dutch Fisheries
}

\author{
Thijs J. Maarleveld
}

\section{Abstract}

This chapter deals with fishing and archaeology. Knowledge held by fishermen has contributed to underwater archaeology's great moments. It is comparable to 'local' knowledge on land, although the locales may be far offshore. To some extent, fishing interests and the management of underwater cultural heritage are at odds but hardly as much as sometimes claimed. Future cooperation with fishermen is of the essence, as the fishing industry has been an essential informer for the development of archaeology offshore, all over the world, and continues to be so. This chapter explores how the development of fishing techniques over the last 150 years has informed prehistoric archaeology of the European continental shelves, notably of the North Sea. It does so through a historical analysis of technological development in its social setting and by highlighting some developments in Dutch fishing communities. It puts collecting of bones and trade in antiquities in perspective. It is mostly concerned, however, with the contingent knowledge base of archaeology and therefore informs archaeological epistemology.

\section{T. J. Maarleveld ( $\square)$}

Maritime Archaeology Programme, University of Southern Denmark, Esbjerg, Denmark

e-mail: t.maarleveld@sdu.dk

\section{Keywords}

Archaeological epistemology $\cdot$ Fishing techniques · Industrial collaboration · Palaeontology $\cdot$ Private collectors .

Underwater cultural heritage

\subsection{Introduction}

This volume provides an overview of the prehistoric archaeology of the European continental shelves. It gives an overview of what we know. Obviously, it occasionally addresses what we do not know or only can infer, but the core is hard evidence. Hard evidence is tangible and measurable. But nevertheless, it is subject to all kinds of contingencies, trends and influences that are not directly measurable or in evidence. So is its interpretation. Doubtless, that is true for all scientific evidence, but here we focus on prehistoric evidence offshore.

What we know of the past is strongly qualified by what is preserved and what is not. That is relatively straightforward, and archaeologists have, therefore, always been preoccupied by physical and taphonomic processes that define preservation of archaeological phenomena, stratigraphy of archaeological sites and physical changes of landscapes (Flemming et al. $2017 \mathrm{a}, \mathrm{b})$. Also, it has long been recognised that abandonment, loss or purposeful deposi- 
tion results in very different forms of preservation as well. Such considerations are quite central to a theoretical understanding of archaeological knowledge. In acknowledgement of Michael Schiffer's seminal book of 30 years ago (Schiffer 1987), all these processes that determine what we know or can know are commonly referred to as formation processes of the archaeological record. But there is more to it than past behaviour or physical preservation. Evidence only exists when it is recognised as such (Maarleveld 2010).

That is what this chapter is about. The logic of scientific discovery (cf. Popper 1935), and the way in which scientists operate, means that they focus on creating discoveries through purposeful action. Offshore, this leads to systematic data capture strategies (Bailey et al. 2017; Missiaen et al. 2017). But research-oriented survey is not by any means the only process through which we create the building blocks of what we know. Harnessing the evidence that industry produces as a by-product of their activities has been fruitful as well (Gaffney et al. 2007, 2009). And for the future, it is undoubtedly important to integrate data capture and research strategies in impact mitigation of offshore development (Maarleveld 2003, 2006; Vos et al. 2015; Pater, Chap. 26, this volume). After all, that is the means by which much archaeological activity is funded and how archaeological services and endeavours are preponderantly organised (Firth 2015). A precondition, however, is that evidence is recognised.

An open mind and awareness of what to look for-and what to be struck by!-is of prime importance for all contingent or systematically organised data gathering. With that in mind, this chapter explores the relationship between contemporary fishing and the knowledge of submerged prehistory that is central to this book. It focuses on the North Sea and on Dutch fisheries. Through the discussion of techniques and mentalities in their historical setting, it reflects on the contingent ways in which archaeological knowledge comes about.

\subsection{Setting and Problem Definition}

Amongst prehistorians, the trawler Colinda is undoubtedly the most famous modern fishing vessel by far. It was, after all, this vessel that brought up the lump of peat in which the barbed antler point of the Leman and Ower Banks was discovered in 1931 (Fig. 27.1; see also Bailey et al. Chap. 10, this volume, Fig. 10.13). The find was recognised as important and promptly published in the influential anthropological journal Man, where it was described as a harpoon of Mesolithic date (Burkitt 1932). The barbed point has been cited as archetypal evidence of submerged prehistory ever since (e.g. Clark 1952,

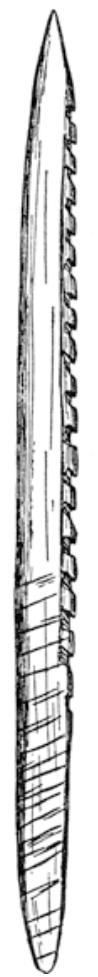

Fig. 27.1 The barbed antler point of the Leman and Ower Banks. It was discovered in a lump of peat that was fished up by the trawler Colinda, registered in Lowestoft as LT 382 in 1931. (Adapted from Clark 1975; see also Bailey et al., Chap. 10, this volume, Fig. 10.13) 
p. 45; Louwe Kooijmans 1972; Clark 1975, p. 134; Momber 2011, p. 92). But in a way, Colinda represents whole fleets of fishing vessels that have impacted prehistoric archaeological remains and that have influenced scientific research.

A regular flow of fishing finds has marked the gradual extension of our knowledge of submerged early prehistory (e.g. Bjerck 1995, p. 133; Sanger 1995 , p. 341) and particularly in the North Sea Basin (Peeters and Amkreutz, Chap. 8, this volume). As elsewhere, some of the artefacts are of flint or stone. Bone and antler objects, however, are far more prominent.

Why do bone artefacts pop up in fishing nets, whereas hand axes and stone maces are mostly found in dredged material? There are several explanations for this. Some are related to deep time, to the specific geological circumstances that embedded the finds after deposition and subsequent preservation. Equally pertinent, however, are the contemporaneous processes that lead to discovery. Some of these processes are general, some are specific to dredging, and some are specific to the fishing industry. No finds become known if no one heeds or registers them. No dredging finds occur in areas where no dredgers are active. Moreover, such finds depend on the way marketable aggregates are separated from overburden and waste and whether separation or transport allows for human observation. Here, we focus on fishing. Fishing techniques differ and have different impacts and results. But the background, knowledge and mind-set of the fishing crews differ as well and are equally important. Both are relevant to understanding the distribution of finds. They are relevant to what we know and what we miss. Both are also relevant to the relationship between archaeologists, fishermen, environmental planning and heritage management.

\subsection{Fishing Techniques}

Colinda was a drifter, a relatively large trawler that mostly used a long trawl of drifting nets with negligible impact on the seafloor. She was a mod- ern, industrial ship with a steam engine, registered at the English port of Lowestoft, owned by a shipping company and manned by a hired captain and crew. It is likely that she occasionally engaged in trawling for flatfish and cod with a so-called otter trawl. Many drifters occasionally did, and it would explain why a lump of peat was brought up in the first place. In fishing with an otter trawl, two otter boards are fastened to a funnel-shaped net (Fig. 27.2). Under motion the boards pull sideways, opening the net. It is a technique that is still widely used today in a wide variety of fisheries. In the North Sea, it used to be the dominant technique for bottom trawling. During the late 1950s and 1960s, the otter trawl gave way to a new technique, the beam trawl, the use of which until then had been limited to shellfishing. In a beam trawl, the mouth of the funnelshaped net is held open by a solid metal beam, attached to a shoe or skid on either side. The skids slide over the sea bottom. For several decades the beam trawl defined Dutch North Sea fisheries. It was effectively the producer of most North Sea palaeontological remains.

Under the beam of the beam trawl and between its two skids, tickler chains are mounted (Fig. 27.3). The chains disturb flatfish and make them swim into the net. Besides tickling fish, this gear obviously catches on any irregularity. Fishermen who are active in environments with rocky outcrops have therefore continued to prefer otter boards, which are less likely to get stuck. For the sandy bottom of the shallow North Sea, however, the beam trawl became paramount. The tickler chains have thoroughly impacted the sediment, stirring up any individual object at (or close to) the surface. Ever fresh material was removed from outcropping contexts. The top layer of the North Sea bottom was systematically ploughed through, removing all sessile life and collecting every conceivable kind of litter into the beam trawling nets. Now in itself, this is not enough to explain the substantial number of stray finds that Dutch fishermen in particular have come up with.

Everything that is caught in a net and comes on board a fishing vessel, but which is not fish, will immediately be dumped. That is to say, it 
Fig. 27.2 Bottom trawling techniques used in North Sea cod and flatfish fisheries. The otter trawl was paramount until it was replaced by the beam trawl in the 1960s. The heavy tickler chains plough through the bottom surface and call for great traction power. During the last 15 years, the beam trawl is gradually being replaced by hovering wings, like the Sumwing and electric pulse ticklers instead of tickler chains.

This means less resistance and a reduction in fuel consumption. A side effect is less bottom impact. Drawing by Thijs Maarleveld

\section{Bottom trawling techniques}
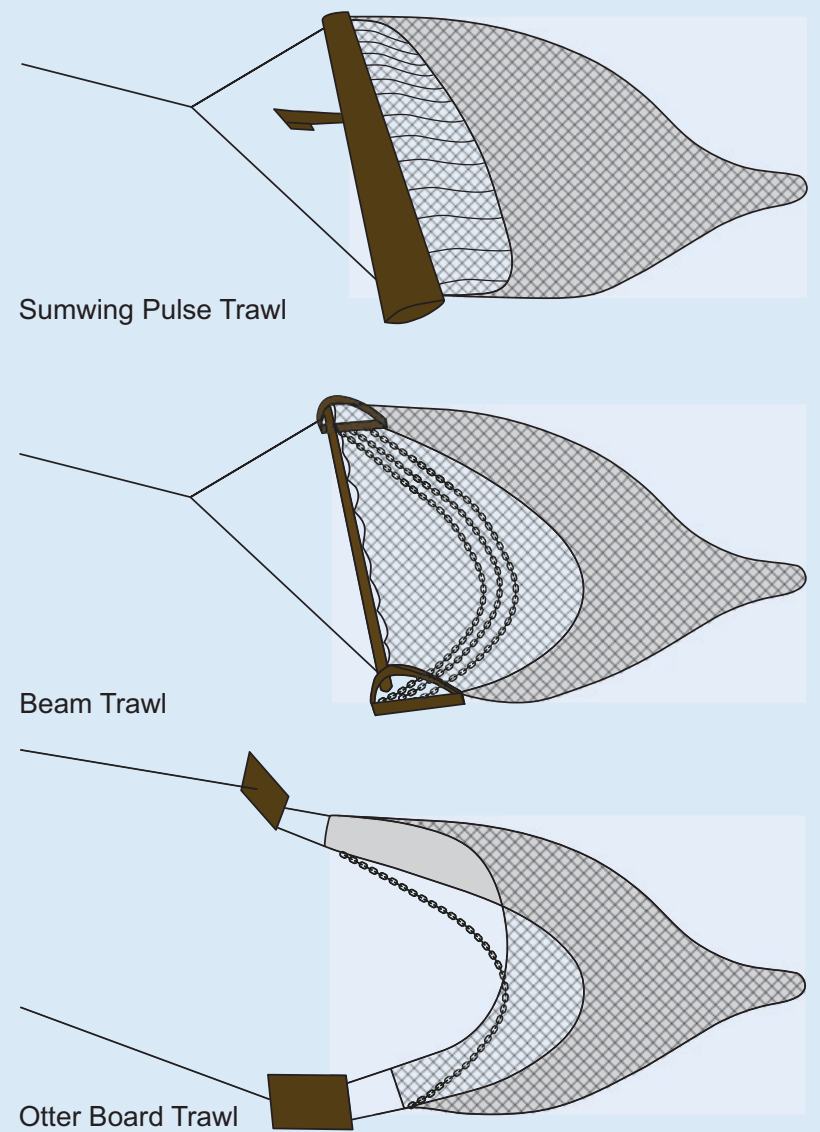

will immediately be dumped unless it is remarkable and therefore remarked on. Peat pellets, wood chips, stones, bricks, bottles and cans are not heeded, and many a hand axe may have gone unnoticed as just another stone. But bones are different, at least amongst the fishermen from Stellendam, Urk, Texel and a few other places. These are three fishing communities in the Netherlands that are closely connected, despite their location in the south, the middle and the north of the country, respectively. The connections between the three communities are reinforced by the fact that they engage in similar types of fishery, organised through similar structures of ship ownership, supply and profit sharing
(Van den Bossche et al. 1999). Moreover, these communities share the same evangelic reformed Protestant creed.

At some point, all three communities consciously engaged in deliberate fishing for bones as an attractive supplementary catch. The story of bone fishing does not, however, start in the North Sea fisheries. It started in the estuarine channels of the Scheldt, the hinterland of the Stellendam fishermen, not in the North Sea itself. From the mid-twentieth century onwards, bone fishing in the Scheldt estuary included some notable fishermen from the town of Zierikzee. It started several generations earlier, however, when fossilised bones were brought up by the traditional sailing 


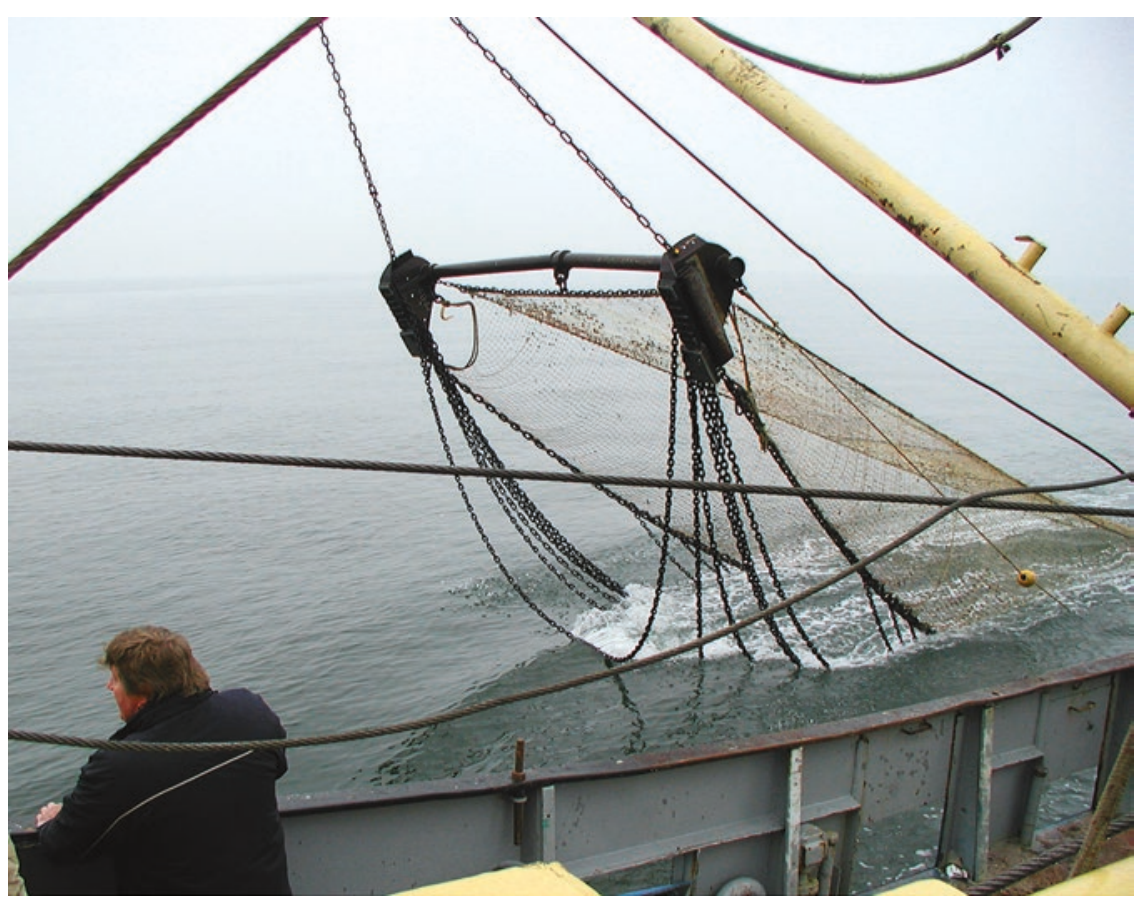

Fig. 27.3 In beam trawling, two funnel-shaped nets are deployed on either side of the trawler. Both are pulled over the sea bottom by great engine force and hauled simultaneously. The metal beam with skids as well as so-called tickler chains can be clearly discerned. Photo by Thijs Maarleveld

craft of the Scheldt estuary, wooden ships no longer than $15 \mathrm{~m}$, with simple bottom tackle and a small crew (Van Beylen 1993; Van Ginkel 1991). From around 1910 onwards, small combustion engines had started to be mounted in these vessels, but certainly not in all, and they were hardly used for more than manoeuvring and running to and from a harbour. Unlike the drifting and lugging industry, the structure of these fisheries or those of Urk and Texel hardly changed until after the closure of the Zuiderzee, the economic crisis of the 1930s and the Second World War (Van Ginkel 1993; Dorleijn 1982-1996).

\subsection{Geographical Setting and Quaternary Geology}

To understand the meaning of the estuarine fisheries in relation to prehistoric archaeological research, it is useful to consider the geology of the area. The landscape of the Netherlands, of which the estuary is a part, is a very young landscape. It is flat. There is no rock. There are hardly any outcrops of early Quaternary or earlier deposits, apart from the area around Maastricht in the far southeast of the country (see also Peeters and Amkreutz, Chap. 8, this volume). In fact, almost all surface deposits in the country and its adjacent sea are much younger (Laban 1995; Berendsen 1996). This is clearly true for recent marine and riverine clays and sands as well as the peat areas and polders. The oldest recognisable landforms derive from the Saalian glaciation and are no more than 100-150,000 years old, but most cover sands date from after the Last Glacial Maximum (20,000 BP). With the area being a subsidence basin, sediments are, however, very deep. In principle, the deep stratigraphy gives a detailed geological record. But in practice it is hardly accessible, unless through coring, deep (=wet) excavation or deep natural erosion. The latter phenomenon is one that is carefully monitored in a country that is prone to 


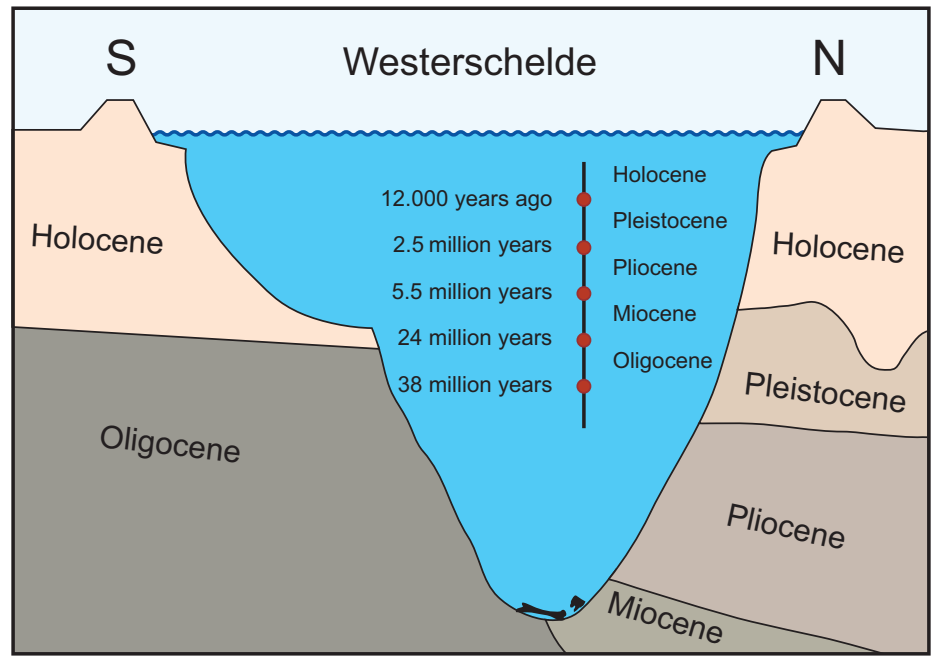

Fig. 27.4 The Scheldt estuary lies on the southern border of the subsidence basin that characterizes the geology of the Netherlands. Erosion pits in the estuary therefore cut through the entire Holocene and Pleistocene sequence but also expose older layers. On the southern side of the Westerschelde, the Holocene immediately overlies the Oligocene. Fossils from all intermediate periods accumulate in the deepest parts of the erosion pits. Drawing by Thijs Maarleveld, after Wetsteyn 2001

and conscious of the risks of dike subsidence and flooding. The estuarine channels of the Scheldt, close to the Belgian border and at the rim of the subsidence basin, are a case in point. Contained between dikes that protect the land from the tides, these channels have cut ever more deeply into ancient sediments. At some points, the erosion channels are more than $40 \mathrm{~m}$ deep (Fig. 27.4).

From 1874 onwards, these deep erosion pits have enjoyed the full attention of geologists and palaeontologists. In that year Dr. J.C. de Man acquired the first fossil bones from an Arnemuiden fisherman for the Scientific Society of Zeeland (Zeeuwsch Genootschap der Wetenschappen, later the Royal Society, Koninklijk Zeeuwsch Genootschap der Wetenschappen). He and many of his successors developed into keen palaeontological specialists of Pleistocene mammals and regularly paid local fisherman to purposefully cast their nets into the deep pits in search of fossils. A large collection was thus built up until around 1930 (Van Nieulande et al. 2017). It contributed enormously to the definition of the Pleistocene fauna, one to two million years ago. Black, strongly fossilised bones of land mammals such as sabre-tooth tiger, early horses, deer and elephants, as well as sea mammals such as seals, walruses and whales are the oldest examples. In everyday language, the Early Pleistocene fauna is referred to as the black bone fauna, despite the fact that several environments are represented (Hooijer 1957; Drees 1986). Incidental finds date even earlier, from the Pliocene or even the Miocene, up to around 10 million years ago. Apparently, reworking gathered together fossils from different ages in the deepest parts of the erosion pits. Fishing in these deep erosion pits thus contributed to science in a major way (Van der Vlerk 1938).

\subsection{The Leiden Connection}

Much to the chagrin of some of Dr. de Man's successors, the active involvement and curation of the Royal Society of Zeeland waned somewhat after the 1930s (Moraal 1964, p. 45). But more fossils were being found, both in deep excavation and in erosion pits where fishermen cast their nets. Not all Zeeland fishermen changed to North Sea fisheries and the beam trawl. While specialising and modernising in different ways, some 


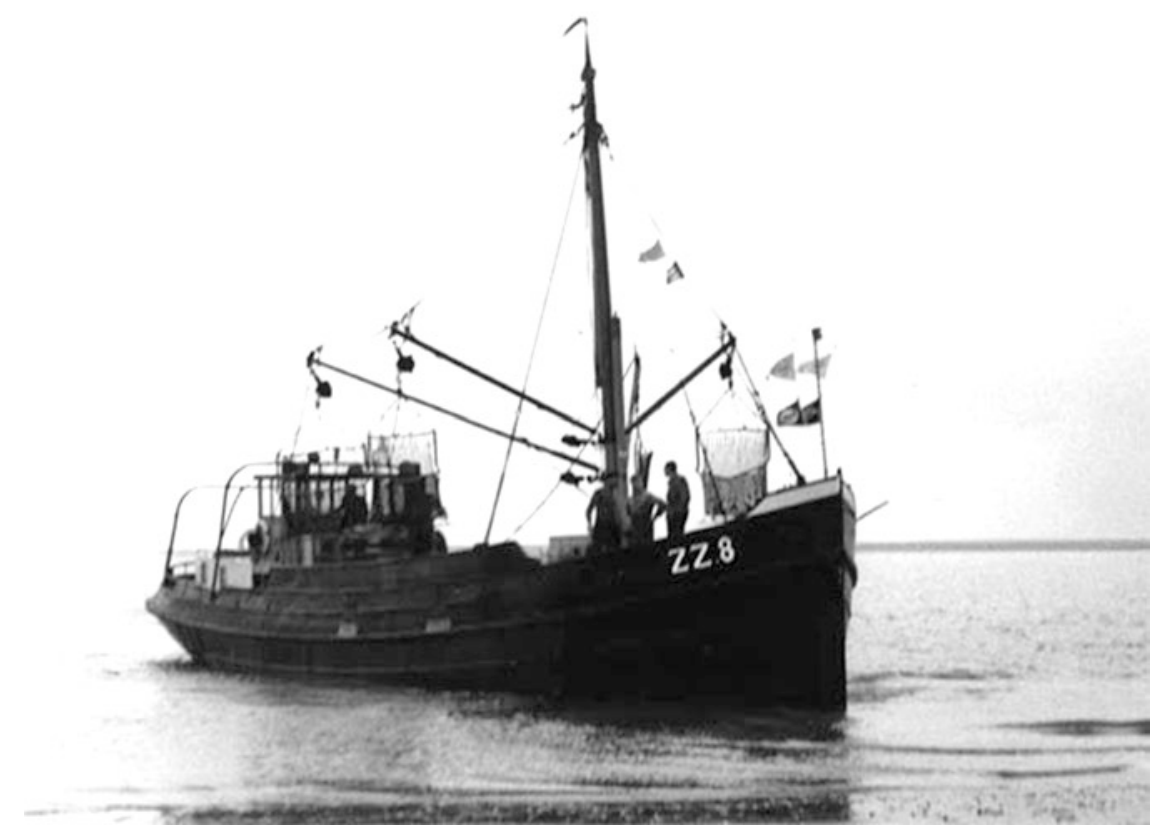

Fig. 27.5 The owners of the shellfish trawler ZZ8 Wilhelmina, the Schot family of Zierikzee, established a close relationship with the staff of the Natural History Museum in Leiden and started to organise yearly fossil hunts in the tidal inlets of the Scheldt estuary in the 1950s. Similar trips had occasionally been organised with the YE7, a fishing vessel from Yerseke as early as 1926. Photo courtesy of Kotterfoto

remained in the estuary, focusing especially on oyster and mussel culture. And some continued their interest in fossils and prehistoric bones, although this was certainly not a very general phenomenon. In pursuit of rare specimens, the Schot family, for instance, who run a mussel enterprise in Zierikzee, used the small beam or rake trawl of their ship in the deeper locations (Fig. 27.5). In pursuit of scientific expertise to identify their finds, they found ready enthusiasm with the then young keeper of Pleistocene palaeontology at the National Museum for Geology and Mineralogy in Leiden. As a consequence, they developed a close cooperation with the museum's staff in the 1950s. The cooperation was formalised into a 'society' with a yearly fieldtrip. The society was called 'Kor en Bot', which means 'Beam-trawl and Bone'.

In 1960 the two scientists directly involved, G. Kortenbout van der Sluijs (Fig. 27.6) and C.J. Overweel, secured a substantial grant. The society went fishing for bones for several months, adding substantially to the understanding of the fauna in Tiglian and Pretiglian times, around 2.5 million years ago. Scientifically, the expedition was a success. A recent quantitative analysis reconfirms this (Scager et al. 2017). But what is perhaps more important in the present context is that it got extensive public exposure. A short but beautifully made documentary in the 'Polygoon' newsreel was shown as a curtain raiser in all cinemas in the Netherlands in 1961. As this is before the media explosion, it is likely that very many would have seen it and been impressed by it. Many fishermen saw their trade depicted on the wide screen - a rare event—and will have realised that bones that they might find could be of interest. Their consciousness was raised, part of their mind-set defined.

Around the same time, collectors of 'black bones' from the Zeeland gullies became aware of toolmarks. Rare finds such as an early Mesolithic antler axe fished from the Westerschelde in 1957 were published by archaeologists (Elzinga 1960). 


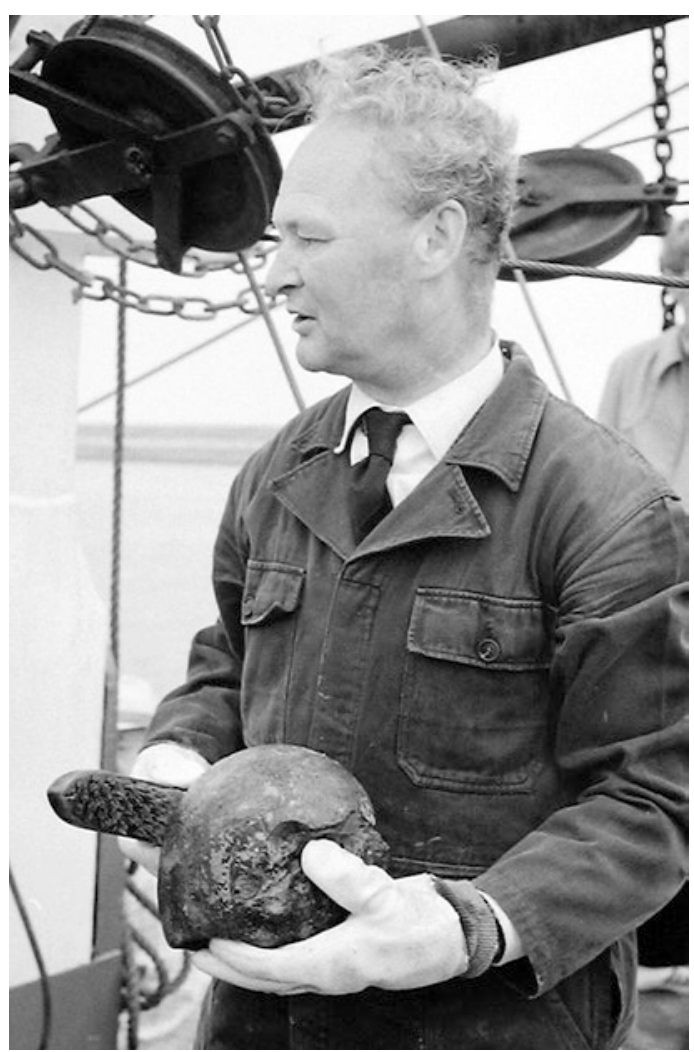

Fig. 27.6 G. Kortenbout van der Sluijs was the palaeontologist behind the promotion of deliberate fishing for fossil bones. There is a deliberate rhyme between his name Kortenbout and the society Kor en Bot. Notable was his expedition of 1961. Here he is photographed in August 1973. Photo by C. Kotvis, courtesy of Zeeuwse Bibliotheek

Such finds aroused substantial interest amongst prehistorians, as the early prehistory of the western part of the Netherlands was largely unknown at the time.

\subsection{The Boom of the 1960s to the 1980s}

It is interesting to consider that this developing awareness occurred at a time when many fishermen were experimenting, adopting the beam trawl and investing in larger and more powerful equipment. While 400 or 600 horsepower (HP) was still considered powerful for a fisherman's main engine in the 1960s, $4000 \mathrm{HP}$ was more the norm in the early 1980s. Also, fishermen developed a better understanding of the extensive fishing grounds of the North Sea and got to know how the beam trawl not only efficiently harvests any fish close to the sea bottom but also disturbs other objects that may be at or close to the bottom surface. Given the background of experience in Zeeland and the consciousness raised by the newsreel in the cinemas, many a find was reported to the palaeontologists at the museum in Leiden as the beam trawlers ploughed their way through much of the North Sea bottom, including those parts where concentrations of large mammal bones occur (Fig. 27.7).

Reports and deliveries sky-rocketed; so much so in fact, that the curators were instructed by management to be very selective in what to accept. Mammoth bones, after all, are recognised more easily, but take up far more space, than the bones of small rodents. The interest, however, had become endemic, and besides the museum in Leiden, other collections were built up, in local museums, in topical displays and in private hands. A very active study group emerged: the study group for Pleistocene mammals, collecting, publishing and exchanging rare fossils. Established in 1983, it continues to be more active than ever. Jointly with the Geoscience Institute at the University of Utrecht, the study group publishes the journal Cranium, which in the 30 years of its existence has built up a solid scientific reputation, integrating and revitalising the early initiatives of the Royal Society of Zeeland (Moraal 1991). Fishing for bones in the North Sea has thus contributed at least as much to science as fishing for bones in the deep erosion gullies of Zeeland. The fossils span a similar range of time, although most North Sea finds relate to the later phases of the Pleistocene, whereas finds from the estuary go back further.

\subsection{Going Commercial}

Before coming back to the relevance for archaeology, a few words should be said on collecting policies. By far the most iconic specimens and the largest amount fished from the North Sea are 


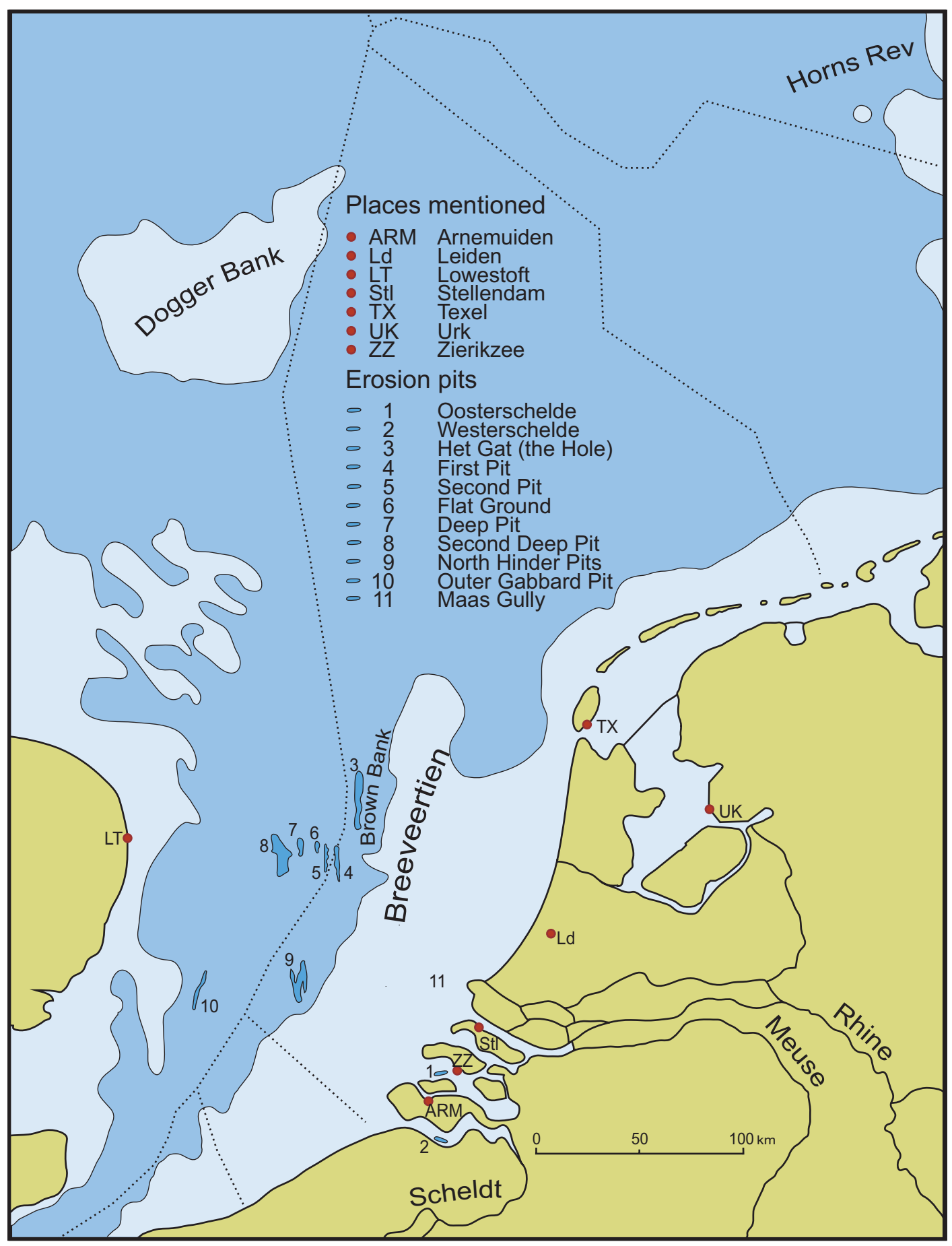

Fig. 27.7 The North Sea with depth contours at 15 and $35 \mathrm{~m}$. The erosion pits of the North Sea that produce most bones are indicated with the colloquial names given by Dutch fishermen. The dredging areas of the Maas gully and the aggregate dredging areas from which other material is recovered, such as Palaeolithic hand axes, are not indicated. For the location of erosion pits in the Westerschelde, the reader is referred to Post and Reumer (2016). The most important cities and fishing ports mentioned in the text are indicated. Drawing by Thijs Maarleveld 


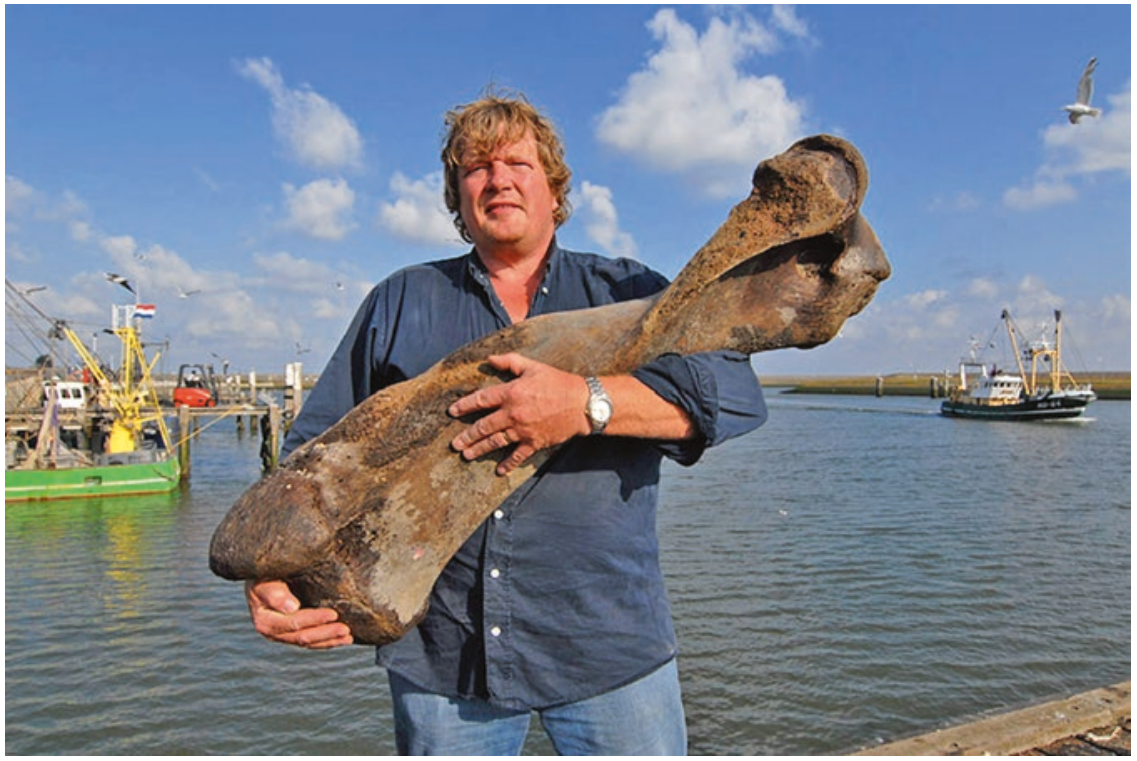

Fig. 27.8 Fisherman and bone collector Adrie Vonk (fishing vessel TX1 Klasina J) brings a mammoth bone to shore in the Texel harbour. Photo by Martijn de Jonge

mammoth (Fig. 27.8). Mammoth teeth were fetching good prices on collectors' markets already long before the Leiden Museum (now Naturalis) decided they wanted to focus on unique specimens rather than wholesale duplicates, irrespective of the unique potential for quantitative analysis of the resource. Being dependent on nature, fishermen tend to have a keen interest in all its phenomena. But even those with little interest would be aware that these teeth were worth keeping, in the spirit of catching and trading whatever fish or other resource can give a profit. Mammoth teeth and femurs are therefore not dumped immediately but put aside as extra earnings. Over the years, a processing routine was developed, integrating knowledgeable collectors as purchasing agents. These instructed the fishermen also to heed smaller and rarer bones. As any stamp collector knows, the unique specimen is more in demand than the item that is already represented. Integrating the activities in the other ports, sorting, describing and trading gradually centred on Urk, from where the worldwide market in fossils and minerals is fed (Fig. 27.9). Needless to say, that fossils and minerals are not generally covered by heritage legislation. Trade is not illegal and not generally covered by measures trying to reduce illicit trade, for instance, under the 1970 UNESCO Convention (Convention on the Means of Prohibiting and Preventing the Illicit Import, Export and Transport of Ownership of Cultural Property) (UNESCO 1970). Nor are Pleistocene mammals, such as the mammoth or the sabre-tooth tiger, endangered species. They have long passed beyond that stage, and trade in these fossilised bones is not subject to the 1973 CITES Convention either (Convention on International Trade in Endangered Species of Wild Fauna and Flora).

\subsection{Archaeology and Natural History}

The Leiden connection, as it was called above, had an important side effect. The National Museum for Geology and Mineralogy and its researchers had a close cooperation with the archaeologists at the National Museum of Antiquities, based in the same city. They helped in petrological analysis of archaeological finds 


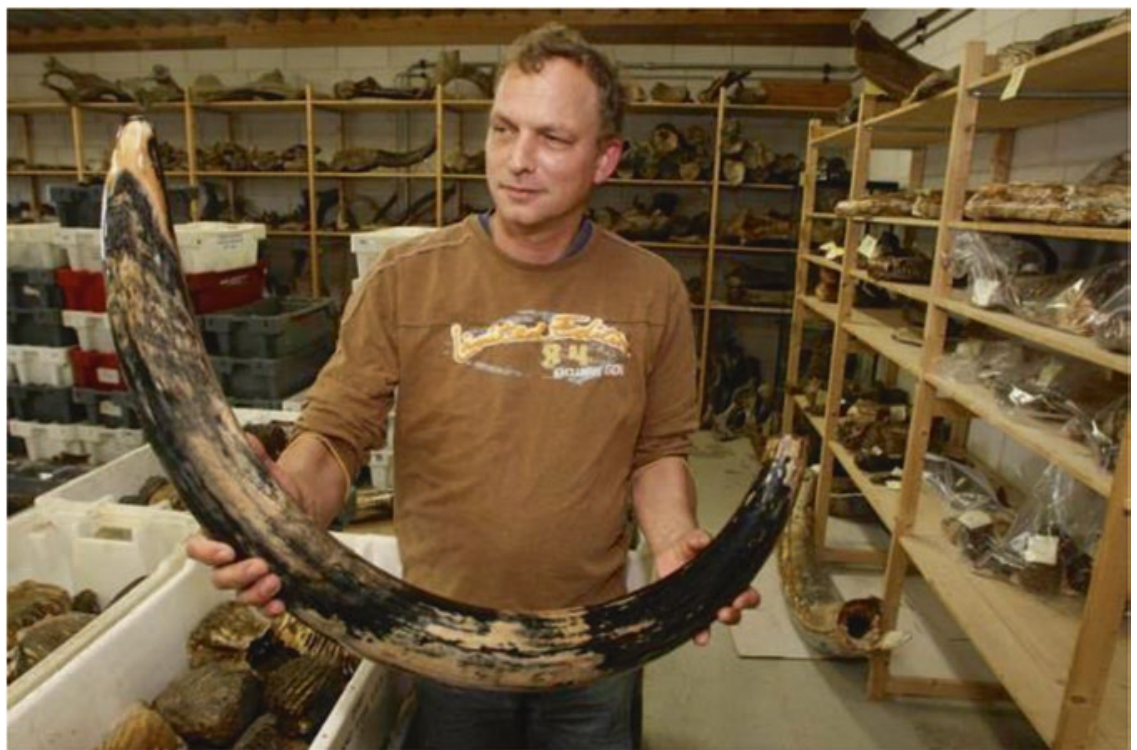

Fig. 27.9 Albert Hoekman at Urk runs a trading business in North Sea fossils and ships them worldwide. Photo by Cees Baars

and generally exchanged information if this was deemed relevant, whether in relation to inland find spots or to fishing finds. In 1970, for instance, the spectacular discovery in the Oosterschelde of the remains of a Roman temple and a plethora of votive altars dedicated to the goddess Nehalennia was brought to archaeological attention through this connection. A major expedition followed, largely based on the fishing methods that had proven themselves in the yearly fieldtrips with the 'Kor and Bot' society. The findspot, after all, was very similar: the remains had gathered in a deep erosion pit in the Oosterschelde, together with much older fossils (Louwe Kooijmans 1971). It was the fishing vessel of skipper Bout from Tholen, TH6 Johanna Cornelia, which was used for the operation.

More important in the present context is that occasional worked bone and antler implements were identified amongst the many fossils that the palaeontologists collected. They confirmed the implication of the barbed antler point of the Colinda, that at least part of the North Sea floor had been inhabited by humans before sea level rose dramatically, and they were systematically studied (Louwe Kooijmans 1972). Many other finds followed. They include not only imple- ments but also 'debitage': pieces of bone and antler that are the discarded waste from the production of artefacts (Fig. 27.10). Some pieces continued to be offered to the National Museum of Antiquities, but others ended up in the many other collections (e.g. Erdbrink 1982; Maarleveld 1984; Glimmerveen et al. 2004; Peeters et al. 2009; Peeters and Amkreutz, Chap. 8, this volume). In private hands, the artefacts became subject to the same practices of exchange that prevail with collections of minerals and fossils. There seems to be no indication, however, that a truly commercial market for these worked bone artefacts has arisen.

With greater awareness about the mysterious existence of 'Doggerland', however, and the possibility of occasional decorated pieces being found, it is in no way inconceivable that an anonymous market exists, even at present, or will arise. Hopefully, collectors will continue to realise that find-context means everything for an archaeological object's scientific value and that even if the find-context is not apparent in detail, the statistical value of every single item is paramount in an area like this (Van der Plicht et al. 2016).

Two things are clear. Beam trawling has thoroughly impacted the bottom of the North Sea. In 


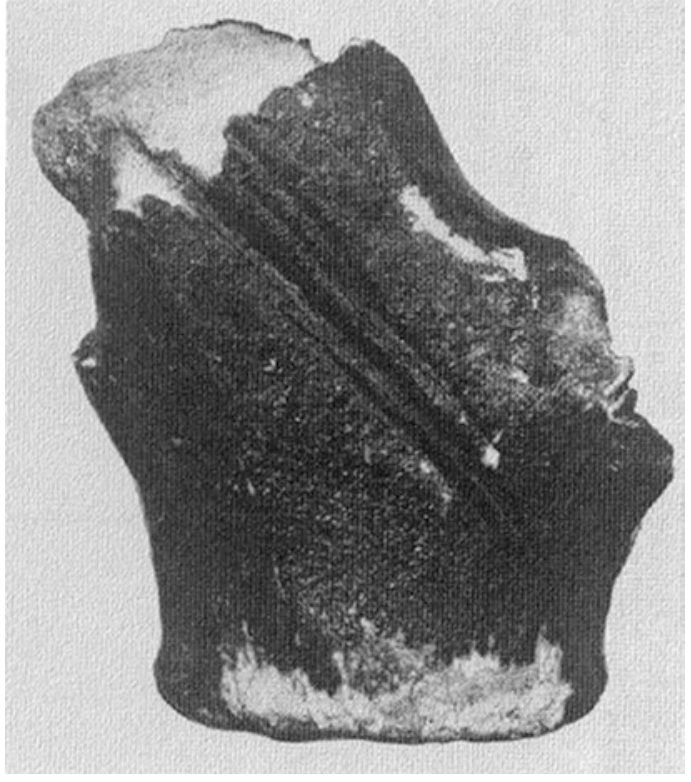

Fig. 27.10 An antler base with grooves stands out amongst the many bones fished from the North Sea bottom. This specimen is from the 'Second Deep Pit' in the Brown Bank area. It is refuse or debitage from the production of bone splinters that are transformed into awls, harpoons or other artefacts. This groove-and-splinter technique is known from early in human prehistory. It is hard to date typologically. Photo by Jan Pauptit, from Maarleveld (1984)

the process many prehistoric artefacts have surfaced, and these are of major scientific significance, not only because, without controlled excavation in the area, they are the best tangible evidence for human activity but also because they represent such a welcome addition to the repertoire of early material culture as we know it (Louwe Kooijmans 1972; Verhart 1995; Verhart 2001). Collections and stray finds from dry land may be more plentiful but are largely composed of fewer types and more durable materials. This is not only a result of preservation but also a result of the selective biases of collection. Bone and antler do not survive under all circumstances; in the North Sea, they do. But also, they are favoured by collection. On board, other materials are quickly thrown out. Due to the processes involved and the knowledgeable awareness of the fishermen described here, bone and antler get special treatment, at least on board Dutch vessels.
Although there are exceptions, most flint and stone artefacts from the North Sea have been collected from the sieves and dumps of aggregate and shell dredging, not through fishing (Tizzard et al. 2015). Beam trawls favour bones.

\subsection{Fishing and Future Finds}

Since the 1980s, bottom-impacting fishing techniques have been much debated worldwide. The use of ever stronger gear and engines, and the fact that slow-growing bottom vegetation is as much affected as fish populations, has made it a major concern for environmentalists (Roberts 2007). Policies were devised to ban these fisheries from specific zones or to limit them to less powerful ships. In North Sea fisheries, the norm for larger trawlers is now $2000 \mathrm{HP}$, almost half of what it was in the 1980s. The fishing techniques themselves have also been under development. Ground tackle like the beam trawl that plods and ploughs with great force is gradually being phased out in favour of tackle of a more hovering kind, including re-designed otter boards, hovering wing-beams and electrical ticklers instead of mechanical ones (Fig. 27.2). Reduction of fuel consumption may be the strongest driving force of this technical development, but the reduction of impact on the sea bottom is a welcome side effect. In that light, the recent decision of the European Union (13 February 2019) to put a ban on electrical ticklers and 'pulse fishing' while approving the less energy effective and more bottom-impacting techniques of mechanical beam trawling seems to be counterintuitive and inspired by the traditional and sometimes irrational fear of technology so comprehensively described by J.H.J. van der Pot (Van der Pot 1985).

With the gradual disappearance of the beam trawl, the heyday of bone fishery may be coming to an end (Vonk 2011). Archaeological layers will be impacted less. This means that better strategies can be devised to investigate them and realise their potential (Peeters et al. 2009). In the Scheldt estuary, the erosion of the northern gul- 
lies has been checked by damming and coastal protection, but important fossils continue to be fished from the deeper pits all the same (Reumer et al. 2005). The southernmost gully, the Westerschelde, is another matter. Deep erosion continues and continues to be monitored as a function of the maintenance of the shipping channel that leads to Antwerp. Deliberate fishing for bones continues as well, with the Schot family and the Royal Zeeland Society focusing on a particularly deep pit near Terneuzen, and other initiatives addressing a range of other erosion pits (Wilde 2007; Post and Reumer 2016). As always, this is not part of normal fishing procedure. In the North Sea, there is another exception, where active fishing for bones and artefacts has been used as what is technically termed an 'Activity directed at Underwater Cultural Heritage' (Maarleveld et al. 2013; see also Dromgoole, Chap. 25, this volume). This expedition was integrated in the monitoring of sand extraction for the Rotterdam Harbour construction (Kuitems et al. 2015).

All in all, there is every reason for archaeology and heritage management to continue and improve their relationship with both the fishing industry and avocational collectors (Firth et al. 2013). The beam trawl may disappear, but occasional finds will still pop up with other fisheries, just as the Colinda point did. Moreover, fishermen are extremely knowledgeable informants on the sea environment, in the North Sea as elsewhere. They are therefore an important partner not only in any potential research initiatives but also in efforts to protect the archaeological and historical elements involved (Maarleveld et al. 2013, pp 267-271). The relationship with collectors is another matter. It will never be without tensions, due to the overlapping yet different interests of scientists, private collectors and public institutions with a brief to streamline heritage management. But that is nothing new in the history of archaeology (Fagan 1975; Schnapp 1996; Watson and Todeschini 2006). In view of the knowledge base discussed in this book, fishermen and collectors have so far played a significant role. For the future we can only hope that this role will not be compromised by the develop- ment of an anonymous market that will foster the loss or falsification of an object's pedigree in pursuit of confidentiality-in pursuit of exclusive possession instead of sharing.

\section{References}

Bailey GN, Harff J, Sakellariou D (eds) (2017) Under the sea: archaeology and palaeolandscapes of the continental shelf. Springer, Cham

Berendsen HJA (1996) De vorming van het land, Inleiding in de geologie en de geomorfologie. Van Gorcum, Assen

Bjerck HB (1995) The North Sea Continent and the pioneer settlement of Norway. In: Fischer A (ed) Man and sea in the Mesolithic. Oxbow, Oxford, pp 131-144

Burkitt MC (1932) A Maglemose harpoon dredged up recently from the North Sea. Man 32:118

Clark JGD (1952) Prehistoric Europe. The economic basis. Methuen, London

Clark G (1975) The earlier Stone Age settlement of Scandinavia. Cambridge University Press, Cambridge

de Wilde B (2007) Fieldtrip to Westerschelde. North Sea Prehistory Newsletter 2

Dorleijn P (1982-1996) Van gaand en staand want. De zeilvisserij voor en na de afsluiting van de Zuiderzee. Van Kampen, Bussum/Van Wijnen, Franeker

Drees M (1986) Kritische kanttekeningen bij de naam 'zwarte botten fauna'. Cranium 3(2):103-120

Elzinga G (1960) Een Lyngby-bijl uit Zeeland. Westerheem 9:102-106

Erdbrink DP (1982) Red deer keratic artefacts in Dutch collections. Berichten Rijksdienst voor het Oudheidkundig Bodemonderzoek 32:103-137

Fagan BM (1975) The rape of the Nile: tomb robbers, tourists, and archaeologists in Egypt. Scribner, New York

Firth A (2015) Risks, resources and significance: navigating a sustainable course for marine development-led archaeology. Bulletin of the Australasian Institute for Maritime. Archaeology 39:1-8

Firth A, McAleese L, Anderson R, Smith R, Woodcock T (2013) Fishing and the historic environment. (EH6204. Prepared for English Heritage). Wessex Archaeology, Salisbury

Flemming NC, Harff J, Moura D, Burgess A, Bailey GN (eds) (2017a) Submerged landscapes of the European continental shelf: Quaternary paleoenvironments. Wiley, Chichester

Flemming NC, Harff J, Moura D (2017b) Non-cultural processes of site formation, preservation and destruction. In: Flemming NC, Harff J, Moura D, Burgess A, Bailey GN (eds) Submerged landscapes of the European continental shelf: Quaternary paleoenvironments. Wiley, Chichester, pp 51-82

Gaffney V, Thomson K, Fitch S (2007) Mapping Doggerland: the Mesolithic landscapes of the southern North Sea. Archaeopress, Oxford 
Gaffney V, Fitch S, Smith D (2009) Europe's lost world: the rediscovery of Doggerland, CBA Research eport 160. Council for British Archaeology, York

Glimmerveen J, Mol D, Post K, Reumer JWF, Van der Plicht H, De Vos J, Van Geel B, Van Reenen G, Pals JP (2004) The North Sea project: the first palaeontological, palynological and archaeological results. In: Flemming NC (ed) Submarine prehistoric archaeology of the North Sea. CBA Research Report 141. Council for British Archaeology, York, pp 43-52

Hooijer DA (1957) Mammals and correlation of the 'Black Bones' of the Schelde estuary with those of the Red Grag. Geologie en Mijnbouw, new series 19:255-256

Kuitems M, Van Kolfschoten T, Busschers F, De Loecker D (2015) The geoarchaeological and palaeontological research in the Maasvlakte 2 sand extraction zone and on the artificially created Maasvlakte 2 beach - a synthesis. In: Moree JM, Sier MM (eds) Interdisciplinary Archaeological Research Programme Maasvlakte 2, Rotterdam. Boorrapporten 566. Gemeente Rotterdam, Rijksdienst voor het Cultureel erfgoed. Port of Rotterdam, Rotterdam, pp 351-398

Laban C (1995) The Pleistocene glaciations in the Dutch sector of the North Sea. A synthesis of sedimentary and seismic data. Proefschrift $(\mathrm{PhD})$ thesis, University of Amsterdam, Amsterdam. ISBN 90-9008587-4

Louwe Kooijmans LP (1971) Oudheidkundige Boomkorvisserij op de Oosterschelde. Westerheem 20:151-188

Louwe Kooijmans LP (1972) Mesolithic bone and antler implements from the North Sea and from the Netherlands. Berichten Rijksdienst voor het Oudheidkundig Bodemonderzoek 20(21):27-73

Maarleveld TJ (1984) 1983, Derde jaar archeologie in Nederlandse wateren. WVC, Rijswijk

Maarleveld TJ (2003) Mitigation as archaeological strategy. The Bulletin of the Australasian Institute for Maritime. Archaeology 27:135-139

Maarleveld TJ (2006) Underwater approaches. Towards mitigation of large-scale disturbances. In: Rensink E, Peeters H (eds) Preserving the early past: investigation, selection and preservation of Palaeolithic and Mesolithic sites and landscapes. Nederlandse Archeologische Rapporten 31, pp 127-137

Maarleveld TJ (2010) Fish and "Chips of Knowledge": Some thoughts on the biases of the archaeological record. In: Bekker-Nielsen T, Bernal Casasola D (eds) Ancient nets and fishing gear. Universidad de Cádiz, Cádiz, pp 256-274

Maarleveld TJ, Guérin U, Egger B (eds.) (2013) Manual for activities directed at underwater cultural heritage. A guide on the rules annexed to the UNESCO 2001 Convention on the Protection of the Underwater Cultural Heritage. UNESCO, Paris

Missiaen T, Sakellariou D, Flemming NC (2017) Survey strategies and techniques in underwater geoarchaeological research: An overview with emphasis on prehistoric sites. In: Bailey GN, Harff J, Sakellariou D (eds) Under the sea: archaeology and palaeolandscapes of the continental shelf. Springer, Cham, pp 21-37

Momber G (2011) Submerged landscape excavations in the Solent, southern Britain: climate change and cultural development. In: Benjamin J, Bonsall C, Pickard C, Fischer A (eds) Submerged prehistory. Oxbow, Oxford, pp 85-98

Moraal JM (1964) De Mens van Zeeland. Grondboor en Hamer 18(2):44-49

Moraal JM (1991) Het Koninklijk Zeeuws Genootschap der Wetenschappen. Cranium 8(/2):88

Peeters H, Murphy P, Flemming N (eds) (2009) North Sea Prehistory Research and Management Framework (NSPRMF) 2009. RCE, Amersfoort

Popper K (1935) Logik der Forschung. Springer, Wien

Post K, Reumer JWF (2016) History and future of paleontological surveys in the Westerschelde Estuary (Province of Zeeland, the Netherlands). DEINSIA 16:1-9

Reumer JWF, Mayhew DF, Van Veen JC (2005) Small mammals from the Late Pliocene Oosterschelde dredgings. DEINSIA 1:103-118

Roberts C (2007) The unnatural history of the sea. The past and future of humanity and fishing. Island Press, Washington

Sanger D (1995) Mesolithic maritime adaptations: the view from North Americas. In: Fischer A (ed) Man and sea in the Mesolithic. Oxbow, Oxford, pp 335-349

Scager DJ, Ahrens H-J, Dieleman FE, Van den Hoek Ostende LW, De Vos J, Reumer JWF (2017) The Kor \& Bot collection revisited, with a biostratigraphic interpretation of the Early Pleistocene Oosterschelde Fauna (Oosterschelde Estuary, the Netherlands). DEINSEA 17:16-31

Schiffer MB (1987) Formation processes of the archaeological record. University of New Mexico Press, Albuquerque

Schnapp A (1996) The discovery of the past: the origins of archaeology. The British Museum Press, London

Tizzard L, Bicket AR, de Loecker D (2015) Seabed prehistory: investigating the palaeogeography and Early Middle Palaeolithic archaeology in the southern North Sea. Wessex Archaeology Report 35. Wessex Archaeology, Salisbury

UNESCO 1970 Convention on the Means of Prohibiting and Preventing the Illicit Import, Export and Transfer of Ownership of Cultural Property - 1970 http:// portal.unesco.org/en/ev.php-URL_ID=13039\&URL_ DO=DO_TOPIC\&URL_SECTION=201.html. Accessed 4 Oct 2017

Van Beylen J (1993) De hoogaars en de visserij van Arnemuiden. Hedeby, Leeuwarden

Van den Bossche M, Van Donselaar P, Van Haselen H, Piers R (1999) De Nederlandse Visserijsector: Economische Betekenis en Structuur. Delft University Press, Delft

Van der Plicht J, Amkreutz LWSW, Niekus MJLT, Peeters JHM, Smit BI (2016) Surf'n turf in Doggerland: Dating, stable isotopes and diet of Mesolithic human 
remains from the southern North Sea. J Archaeol Sci Rep 10:110-118. https://doi.org/10.1016/j. jasrep.2016.09.008

Van der Pot JHJ (1985) Die Bewertung des technischen Fortschritts. Eine systematische Übersicht der Theorien. Van Gorcum, Assen/Maastricht

Van der Vlerk IM (1938) Nederland in het IJstijdvak. Oratie, Leiden

Van Ginkel R (1991) Elk vist op zijn tij: Een Zeeuwse maritieme gemeenschap, Yerseke. Walburg Pers, Zutphen, pp 1870-1914

Van Ginkel R (1993) Tussen Scylla en Charybdis. Een Ethnohistorie van Texels vissersvolk. Het Spinhuis, Amsterdam, pp 1813-1932

Van Nieulande F, Bosselaers M, Loeff H, Bekker JP (2017) Natuurhistorische voorwerpen http://www. kzgw.nl/index.php/collecties/natuurhistorische-voorwerpen. Accessed 4 Oct 2017

Verhart LBM (1995) Fishing for the Mesolithic. The North Sea: a submerged Mesolithic landscape. In:
Fischer A (ed) Man and sea in the Mesolithic. Oxbow, Oxford, pp 291-302

Verhart L (2001) De zee neemt, de zee geeft. Spectaculaire vondsten uit de Noordzee. Westerheem 50(3):102-108

Vonk A (2011) Vissers vangen bot. Unpublished presentation Noordzeedagen, Leeuwarden

Vos PC, Bunnik FPM, Cohen KM, Cremer H (2015) A staged geogenetic approach to underwater archaeological prospection in the Port of Rotterdam (Yangtzehaven, Maasvlakte, The Netherlands): A geological and palaeoenvironmental case study for local mapping of Mesolithic lowland landscapes. Quatern Int 367(5):4-31. https://doi.org/10.1016/j. quaint.2014.11.056

Watson P, Todeschini C (2006) The Medici conspiracy: the illicit journey of looted antiquities, from Italy's tomb raiders to the world's greatest museums. Public Affairs, New York

Wetsteyn B (2001) Fossielen in de Westerschelde. Schelde Nieuwsbrief 27:4

Open Access This chapter is licensed under the terms of the Creative Commons Attribution 4.0 International License (http://creativecommons.org/licenses/by/4.0/), which permits use, sharing, adaptation, distribution and reproduction in any medium or format, as long as you give appropriate credit to the original author(s) and the source, provide a link to the Creative Commons licence and indicate if changes were made.

The images or other third party material in this chapter are included in the chapter's Creative Commons licence, unless indicated otherwise in a credit line to the material. If material is not included in the chapter's Creative Commons licence and your intended use is not permitted by statutory regulation or exceeds the permitted use, you will need to obtain permission directly from the copyright holder.

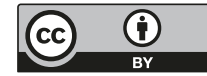

